\title{
INTERNALISASI MATA KULIAH STUDI SYARIAT ISLAM DI ACEH DALAM KURIKULUM UIN AR- RANIRY BANDA ACEH
}

\author{
Mukhlisah, Salma Hayati \\ Universitas Islam Negeri (UIN) Ar-Raniry Banda Aceh \\ Mukhlisah.falah@gmail.com, salma_uinarraniry@yahoo.co.id
}

\section{Abstrak}

The Ar-Raniry Islamic University of Banda Aceh since the 2014/2015 Academic Year makes the Study of Islamic Sharia in Aceh as a universityfinding course that must be studied by all students. The purpose of this study is to find out the background of the birth of the Islamic Sharia Study course in Aceh in the Ar-Raniry UIN curriculum and the competencies expected to be achieved by students through this course. A qualitative approach through interview techniques is used to obtain data and information. Stakeholders (Vice Rector 1 and Director of PPs UIN Ar-Raniry and Head of the Islamic Sharia Service) and 1 lecturer as the subject of the study. Data analysis uses descriptive analysis by following the steps of Miles and Hubberman's theory (data reduction, data presentation and data verification or drawing conclusions). The results of the study that the internalization of Islamic Sharia Studies courses in Aceh in the Ar-Raniry UIN curriculum is motivated by several factors, namely; first the Islamic Sharia is a deeply rooted part in Acehnese society, the second Islamic Sharia in Aceh has received the formality of the state, and thirdly UIN Ar-Raniry has moral responsibility for the implementation of Islamic Sharia in Aceh. The competencies that are expected to be achieved by students are to understand the Islamic Sharia in Aceh in depth and comprehensively as well as the realization of Sharia awareness that is engraved in practice (to do) and behavior (to be).

Keyword: Internalisasi, Syariat, Islam, Kurikulum 


\section{A. PENDAHULUAN}

Pembahasan tentang Syariat Islam (SI) dalam konteks Indonesia yang juga memiliki kemajemukan aspek agama maka terbayang sebuah provinsi paling ujung barat pulau Sumatera, yaitu Provinsi Aceh. Hanya provinsi ini yang diberi kewenangan menerapkan SI dalam NKRI. Legalitas pelaksanaannya dengan dikeluarkan UU No. 22 Tahun 1999, UU NO. 44 Tahun 1999, UU No. 18 Tahun 2001, serta lahirnya Perda-Perda yang mengatur proses pelaksanaan SI di Aceh, diantaranya Perda No. 3 Tahun 2000 tentang Majelis Permusyawaratan Ulama (MPU), Perda No. 5 Tahun 2000 tentang Pelaksanaan SI, Qanun No. 12 Tahun 2003 tentang Minuman Khamar dan sejenisnya, dan lain-lain.

Syariat Islam hakikatnya mempunyai makna luas mencakup aqidah (teologi Islam), prinsip-prinsip moral (etika dan karakter Islam, akhlak) dan peraturan-peraturan hukum (fikih) yang bersumber pada Al-Qur'an dan alSunnah. ${ }^{1}$ Pengertian ini tidak berbeda dengan makna pendidikan Islam yang mempunyai makna sangat luas mencakup seluruh peri kehidupan manusia. Syariat datang dari Allah, mengandung aspek-aspek aqidah, syariah, ibadah, akhlak, sains, teknologi, sosiologi, politik, ekonomi dan lain-lain. ${ }^{2}$ Maka penerapan SI harus mencakup semua aspek tersebut.

Realitas yang ada bahwa penerapan SI di Aceh masih jauh dari harapan, belum terlaksana dengan baik bahkan disebutkan masih dalam pencarian format, ${ }^{3}$ pelaksanaannya belum tersusun secara baik dan masih bersifat TnE (trial and error). ${ }^{4}$ Di sisi lain penerapan SI di Aceh menimbulkan banyak persoalan,n benturan dan isu yang dikaitkan dengan SI, seperti isu HAM, gender, non muslim, dan lain sebagainya. ${ }^{5}$ Menyikapi hal ini, menjadi tanggung jawab berbagai pihak agar SI di Aceh terlaksana secara kaffah sehingga akan menjadi rahmatan lil 'alamin khususnya masyarakat Aceh. Manifestasinya terwujud

Mujiburrahman, dkk., Pendidikan Berbasis Syariat Islam di Aceh, (Banda Aceh: Dinas Syariat Islam Aceh, 2011), hal. 7; M. Syaltout, Islam: Aqidah wa Syariah, (Cairo: Dar al-Qalam , 1966), hal. 12.

2 Ahmad, dkk., Islam dalam Pendidikan dan Hubungannya dengan Pembentukan jati Diri Bangsa Melayu di Malaysia. Jurnal Hadhari Special Edition, 2012: 37-50.

3 Syamsul Bahri, Konsep Implementasi Syariat Islam di Aceh. Kanun Jurnal Ilmu Hukum, 60 (XV), 2012: 313-337; Abdullah Sani Usman. Cabaran dan Halangan dalam Pelaksanaan Undang-Undang Jenayah Syariah Islam. Jurnal Pengajian Umum Asia Tenggara. Vol. 12, 2011:5-14.6

4 Al Yasa Abu Bakar, Pelaksanaan Syariat Islam (Sejarah dan Prospek), (Banda Aceh, Dinas Syariat Islam Pemerintah Aceh, 2002), hal. 45.

5 Sulaiman, Studi Syariat Islam di Aceh, (Banda Aceh: Madani Publisher, 2018), hal. 165. 
dalam kehidupan individual, kemasyarakatan serta kelembagaan yang ada di bumi serambi Mekkah.

Sehubungan dengan persoalan ini, Universitas Islam Negeri (UIN) ArRaniry tentunya memiliki tanggungjawab untuk menjawab masalah yang ada. UIN Ar-Raniry merupakan lembaga pendidikan tinggi Islam formal tertua di Provinsi Aceh yang mempunyai visi ${ }^{6}$ dan misi $^{7}$ sejalan dengan syariat Islam. Maka bentuk konkritnya adalah dengan menambah satu mata kuliah yang mencirikan SI yaitu Studi Syariat Islam di Aceh dalam kurikulum yang dilaksanakan dalam bentuk kurikuler. Mata kuliah ini tidak dijumpai di universitas-universitas lain di Aceh. Mata kuliah ini nampaknya memiliki karakteristik tersendiri bagi UIN Ar-Raniry karena mencirikan kekhasan Aceh sebagai daerah yang menerapkan SI.

Internalisasi mata kuliah ini ke dalam kurikulum UIN Ar-Raniry barangkali mengambil model konsep kurikulum rekonstruksi sosial yang memandang bahwa kurikulum dikembangkan berdasarkan potensi dan karakteristik daerah. ${ }^{8}$ Penambahan mata kuliah ini di UIN Ar-Raniry sebagai bentuk konkrit UIN Ar-Raniry menyahuti amanat Undang-undang Republik Indonesia Nomor 11 Tahun 2006 tentang Pemerintah Aceh Pasal 16 ayat 2 point c, yaitu penyelenggaraan pendidikan di Aceh yang berkualitas serta menambah materi muatan lokal sesuai dengan syariat Islam. Maka mata kuliah ini nampaknya dapat dikatakan sebagai mata kuliah muatan lokal dalam kurikulum UIN ArRaniry. Internalisasi mata kuliah ini di institusi UIN Ar-Raniry patut diberi apresiasi karena sudah ada upaya lembaga pendidikan dalam memberi wawasan keilmuan kepada mahasiswa tentang kajian SI di Aceh. Namun meskipun demikian, internalisasi mata kuliah ini dalam kurikulum UIN Ar-Raniry pasti ada faktor urgensitasnya. Maka tulisan ini mencoba memaparkan sisi urgensitas dari internalisasi mata kuliah Studi Syariat Islam di Aceh dalam kurikulum UIN Ar-Raniry.

${ }^{6}$ Menjadi universitas yang unggul dalam pengembangan dan pengintegrasian ilmu keislaman, sains, teknologi dan seni.

Melahirkan sarjana yang memiliki kemampuan akademik, profesi dan atau vokasi yang kompetitif, berorientasi, pada masa depan dan berakhlak mulia, mengembangkan tradisi riset yang multidisipliner dan integratif berbasis syariat Islam, serta mengimplemetasikan ilmu untuk membangun masyarakat madani yang beriman, berilmu, dan beramal.

8 Nana Sudjana, Dasar-dasar Proses Belajar Mengajar, Bandung: Sinar Baru Algesindo, 2005), hal. 18. 


\section{B. SYARI'AT ISLAM}

Syariat Islam (SI) didefinisikan dengan aturan/hukum yang ditetapkan Allah melalui al-Quran dan Sunnah sebagai pedoman hidup bagi manusia untuk mencapai ridha Allah. ${ }^{9}$ Ketetapan syariat meliputi aspek aqidah/keyakinan, amaliyah/fikih dan akhlak/tasawuf. ${ }^{10}$

Pelaksanaan SI di Aceh adalah impian masyarakat Aceh sejak lama sebagai upaya mewujudkan keadilan dan kemaslahatan sosial. Walaupun dalam implementasinya kesadaran bersyariat masyarakat masih cenderung formalistik-pragmatis, parsialistik-disintegratif dan reaktif. ${ }^{11}$ Prinsip penerapan SI di Aceh untuk mengimplementasikan ajaran-ajaran yang terkandung dalam Al-Quran. ${ }^{12}$ Prinsip pelaksanaannya tertuang dalam Qanun Nomor 11 Tahun 2002 tentang pelaksanaan SI bidang aqidah, ibadah dan syi'ar Islam. Dalam pandangan Sulaiman, pelaksanaan SI di Aceh harus memperhatikan prinsip; berlandaskan Al-Quran dan Hadis, menjamin keadilan hukum, pertumbuhan ekonomi masyarakat, politik yang islami, serta sosio-kultural masyarakat Aceh. ${ }^{13}$

Pelaksanaan SI di Aceh bertujuan untuk mewujudkan kesempurnaan hidup kaum muslim, aman, tenteram, sejahtera sosial-ekonomi, serta hidup dalam aturan yang sesuai dengan kesadaran hukum dan ras keadilan. ${ }^{14}$ Dalam qanun disebutkan tujuan dan fungsi pelaksanaan SI di Aceh untuk; (1) membina dan memelihara keimanan dan ketaqwaan individu dan masyarakat dari pengaruh sjaran sesat; (2) meningkatkan pemahaman dan pengamalan ibadah serta penyediaan fasilitasnya; serta (3) menghidupkan dan menyemarakkan kegiatan-kegiatan guna menciptakan suasana lingkungan yang islami.

Pokok-pokok pelaksanaan SI di Aceh diatur dalam Qanun Nomor 8 Tahun 2014 bahwa SI mencakup seluruh aspek kehidupan masyarakat dan apara-

9 Muhammad Hendra, Pendidikan Agama Islam, (Yogyakarta: Deepublish, 2014), hal. 101.

${ }^{10}$ Azman Ismail, dkk., Syariat Islam di Nanggroe Aceh Darussalam, (Banda Aceh: Dinas Syariat Islam, 2011), hal. 68.

${ }^{11}$ Sirajuddin M, Legitimasi Pemberlakukan Syariat Islam di NAD: Analisis Prinsip-prinsip dan Peluang Yuridis Konstitusional, SOSIO RELIGIA, 10(1): 74.

${ }^{12}$ Diantaranya; ajakan beriman kepada Allah, mencari ridha-Nya (QS.An-Nisa:6), menjalankan perintah Allah (QS. An-Nisa: 59), meninggalkan larangan Allah (QS. Ali Imran: 104), mengamalkan, menyebarkan, dan memajukan semua hukum-hukum Allah (QS. Al-jatsiyah: 18) (Hasanuddin Yusuf Adan, Syariat Islam dan Politik Lokal di Aceh, (banda Aceh: 'Adnin Foundation Group, 2016), hal.27.

${ }^{13}$ Sulaiman, Studi Syariat..., hal.7.

${ }^{14}$ Azman Ismail, Syariat Islam..., hal. 12. 
tur di Aceh yang pelaksanaannya mencakup aspek aqidah, syariah dan akhlak. Pelaksanaan aspek syariah mencakup ibadah, ahwal al-syakbshiyah, muamalah, jinayat, qadha', tarbiyah dan pembelaan Islam. Pelaksanaan aspek akhlak meliputi syiar dan dakwah.

Masyarakat dan pemerintah Aceh memiliki tanggung jawab bersama untuk keberhasilan terlaksananya SI di Aceh. tanggung jawab permintah diatur dalam Qanun Nomor 8 Tahun 2014 bahwa pemerintah berkewajiban mengembangkan, meningkatkan pemahaman aparatur pemerintahan dan masyarakat, membimbing dan mengawasi pelaksanaan SI dengan sebaik-baiknya. Sementara masyarakat, (setiap orang) yang menetap di Aceh wajib menghormati dan mematuhi pelaksanaan SI di Aceh. Qanun Nomor 8 Tahun 2014 mengatur; (1) Setiap orang beragama Islam di Aceh wajib mentaati dan mengamalkan Syariat Islam; dan (2) Setiap orang atau badan hukum yang berdomisili atau berada di Aceh wajib menghormati pelaksanaan Syariat Islam.

Beberapa institusi yang memiliki keterkaitan dengan pelaksanaan SI di Aceh, yaitu; Dinas Syariat Islam (Dinsyar) dibentuk oleh pemerintah Aceh. Lembaga ini merupakan birokrasi pemerintah yang mengurus bidang penerapan SI di Aceh. Dinas ini sebagai penanggung jawab perencanaan dan pelaksanaan SI, terutama berkaitan dengan rancangan qanun, menyiapkan tenaga dan sarana, membantu dan menata penyelenggaraan peribadatan, mengawasi pelaksanaan SI serta memberikan bimbingan dan penyuluhan. ${ }^{15}$

Institusi lainnya adalah wilayatul Hisbah sebagai unit organisasi yang memiliki peran penting terhadap pengawasan pelaksanaan SI di Aceh. ${ }^{16}$ Institusi ini bertugas mengawasi, melakukan pembinaan dan advokasi terhadap pelaksanaan peraturan perundang-undangan bidang SI dalam rangka melaksanakan amar ma'ruf nabi munkar. ${ }^{17}$

Mahkamah Syar'iyyah juga institusi yang memiliki keterkaitan dengan pelaksanaan SI di Aceh. Institusi ini adalah perubahan dari Peradilan Agama (PA) yang hanya ada di provinsi Aceh. Kewenangannya dalam pelaksanaan SI diatur dalam Qanun Nomor 10 Tahun 2002 yaitu memutus dan menyelesaikan perkara-perkara pada tingkat pertama dalam bidang ahwal al-syakhshiyah, mu’amalah, dan jinayah.

${ }^{15}$ Muhibbuthabry, Kelembagaan Wilayat Al-Hisbah di Aceh (Konsep dan Implementasi, (Banda Aceh: Pena, 2010), hal. 75.

${ }^{16}$ Sulaiaman, Studi Syariat..., hal. 133.

${ }^{17}$ Hasanuddin Yusuf Adan, Refleksi Implementasi Syariat Islam di Aceh, (banda Aceh: Adnin Foundation Publisher, 2009), hal. 29. 
Selain itu, Majelis Permusyawaratan Ulama (MPU) adalah institusi yang turut terkait dengan pelaksanaan SI di Aceh. Instutusi ini sebagai institusi pengganti MUI untuk provinsi Aceh yang memiliki peran memberikan pertimbangan dalam bentuk fatwa, tausiah atau rekomendasi. ${ }^{18}$ Kewenangan MPU diatur dalam Qanun Nomor 2 Tahun 2009 yaitu; (1) menetapkan fatwa terhadap pemerintah, pembangunan, ekonomi, sosial budaya dan kemasyarakatan; dan (2) memberikan arahan terhadap perbedaan pendapat dalam masalah keagamaan baik sesama umat Islam maupun antar umat beragama lainnya.

Baitu Mal merupakan institusi pengumpulan dan pengelolaan zakat di Aceh. Dalam qanun disebutkan institusi ini sebagai lembaga yang berwenang melakukan tugas pengelolaan zakat, infaq dan harta agama lainnya di provinsi Aceh. Tujuannya untuk kemaslahatan umat serta menjadi wali/wali pengawas terhadap anak yatim piatu dan/atau hartanya serta pengelolaan terhadap harta warisan yang tidak ada wali berdasarkan SI. ${ }^{19}$

\section{INTERNALISASI MATA KULIAH STUDI SYARI'AT ISLAM DALAM KURIKULUM DI UIN AR RANIRY BANDA ACEH}

Studi syariat Islam di Aceh menjadi bahan kajian baru yang diajarkan secara kurikuler di UIN Ar-Raniry. Secara formal kajian ini dijadikan sebagai mata kuliah baru yang direncanakan dan disusun dalam dokumen kurikulum UIN Ar-Raniry. Mata kuliah ini merupakan mata kuliah dasar umum atau mata kuliah dengan kode/penciri universitas yang wajib diikuti oleh semua mahasiswa yang belajar di UIN Ar-Raniry. Kajian ini menemukan dua hal terkait internalisasi mata kuliah ini dalam kurikulum UIN Ar-Raniry, yaitu latar belakang lahirnya mata kuliah Studi Syariat Islam di Aceh dan kompetensi yang diharapkan dicapai oleh mahasiswa dalam mata kuliah ini.

\section{Latar Belakang Lahirnya Mata Kuliah Studi Syariat Islam di Aceh dalam Kurikulum UIN Ar-Raniry}

Hasil kajian menemukan beberapa alasan mendasar yang dianggap urgen sehingga dijadikan Studi Syariat Islam di Aceh sebagai mata kuliah di UIN Ar-Raniry, yaitu: Pertama, Perubahan Nomenklatur Lembaga. Penjelasan in-

\footnotetext{
${ }^{18}$ Abidin Nurdin, Reposisi Peran Ulama dalam Penerapan Syariat Islam di Aceh, Jurnal AlQalam, 18 (1) 2012: hal. 60.

19 Sulaiman, Studi Syariat Islam..., hal. 147.
} 
forman bahwa:

"Yang melatar belakangi munculnya mata kuliah Studi Syariat Islam di Aceh di UIN Ar-Raniry tidak terlepas dari perubahan IAIN menjadi UIN ArRaniry. Saya memikirkan bagaimana merubah wajah institusi menjadi sebuah universitas, lalu kita analogikan dengan universitas Islam lain yang ada di PTKIN maka kita melihat contoh atau kiblat kita adalah Malang. Perubahan nomenklatur ini yang berdampak pada perubahan struktur termasuk perubahan kurikulum. Bicara kurikulum di UIN maka bicara tentang seluruh perangkat-perangkat yang menopang, mendukung, mendorong perguruan tinggi menjadi lebih baik. Framework kurikulum dilakukan secara deduktif (piramida terbalik), yaitu ada kurikulum dan susunan rangkaian mata kuliah termasuk di dalamnya mata kuliah baru yaitu Studi Syariat Islam di Aceh".

Pada tahun 2013 secara resmi lembaga IAIN Ar-Raniry berubah menjadi UIN Ar-Raniry berdasarkan Peraturan Presiden Nomor 64 Tahun 2013 dan Peraturan Menteri Agama (PMA) Republik Indonesia No 12 Tahun 2014 tentang Organisasi dan Tata Kerja Universitas Islam Negeri Ar-Raniry Banda Aceh. Perubahan ini berpengaruh kepada perubahan sistem lembaga termasuk kurikulum. Lalu dilakukan kajian-kajian terhadap kurikulum yang ada (yang masih berkonsep institut) untuk disesuaikan dengan konsep universitas berbasis Islam dan karakteristik lembaga serta daerah. Maka perubahan IAIN ArRaniry kepada UIN Ar-Raniry berdampak pada perubahan kurikulum, diantaranya adalah terjadi penambahan mata kuliah baru yaitu Studi Syariat Islam di Aceh dalam kurikulum.

Perubahan IAIN menjadi UIN harus berdampak positif bagi lembaga dan alumni. Perubahan ini diharapkan membawa perubahan pengetahuan dan pemikiran segenap alumni dalam kesiapan memasuki kehidupan era globalisasi dan teknologi informasi. Marwan menjelaskan perubahan IAIN menjadi UIN slah satunya diharapkan agar tercipta "intelektual yang alim" dan "ulama yang intelektual” sehingga alumni UIN memiliki nilai lebih dalam bidang keilmuan dan keahlian yang dibutuhkan di lapangan, memiliki pengetahuan/dasar agama yang kuat sebagai pembentukan akhlak dan moral untuk kemudian siap terjun dalam dunia kerja dan bermanfaat untuk masyarakat. ${ }^{20}$

Kedua, karakteristik daerah. Informan memandang "terkonversinya IAIN menjadi UIN tidak terlepas dari landasan pokok UU No. 44 tahun 1999 tentang keistimewaan Aceh. Salah satu keistimewaannya adalah penerapan Syariat

\footnotetext{
${ }^{20}$ Marwan Salahuddin, Model Pengembangan Pendidikan Tinggi Islam di Indonesia, Jurnal
} Studi Keislaman Ulumuna, 18 (1) 2014: 121-138. 
Islam”. Provinsi Aceh melalui UU No. 44 Tahun 1999 diberi keistimewaan oleh pemerintah pusat untuk menyelenggarakan beberapa hal yang meliputi; penyelenggaraan kehidupan beragama, kehidupan adat, pendidikan, dan peran ulama dalam penetapan kebijakan daerah. Kewenangan teristimewa adalah pelaksanaan syariat Islam tertuang dalam Peraturan Daerah No. 5 Tahun 2000 dan ini merupakan karakteristik daerah Aceh yang tidak dimiliki oleh daerah-daerah lain di Indonesia.

Penerapan syariat Islam di Aceh adalah kekhasan daerah Aceh. Maka kehadiran mata kuliah Studi Syariat Islam di Aceh dalam kurikulum UIN ArRaniry dipandang penting sebagai wujud konkrit dan riil kepedulian lembaga pendidikan di Aceh yang ikut bertanggung jawab keterlaksanaan undangundang. UIN Ar-Raniry dengan wajah barunya melakukan pembenahanpembenahan sistem lembaga termasuk penyempurnaan pada aspek kurikulum. Pengambil kebijakan (stakeholder) UIN Ar-Raniry melihat perlu merumuskan kurikulum yang mencerminkan kekhasan lembaga, menyesuaikannya dengan visi dan misi lembaga. Maka satu kekhasan kajian yang dianggap perlu adalah kajian Syariat Islam di Aceh. Mata kuliah yang mengkaji SI belum ditemukan di lembaga-lembaga pendidikan lain di Aceh. Maka dengan berbagai pertimbangan, alasan dan perjuangan yang berat dan panjang diputuskan untuk dijadikan Studi Syariat Islam di Aceh sebagai mata kuliah yang mencirikan kekhasan UIN Ar-Raniry. Informan berpandangan bahwa:

"Mata kuliah ini sebagai wujud konkrit dari kekhasan atau karakteristik UIN Ar-Raniry. Lalu menurut kami mata kuliah ini harus terakomodir dalam kurikulum UIN Ar-Raniry. Lalu sebagai implikasi dari frame work kurikulum yang kita bangun dari tahun 2014 maka mata kuliah Studi Syariat Islam di Aceh merupakan mata kuliah wajib bagi seluruh mahasiswa di seluruh fakultas yang ada di UIN Ar-Raniry".

Syariat Islam di Aceh sebagai bentuk kekhasan daerah Aceh akan menjadi tidak bermakna ketika hanya ditemukan di dalam sejarah. Akan tetapi akan lebih memiliki nilai ketika ia diajarkan sebagai sebuah ilmu yang resmi dalam kurikuler sebuah lembaga. Dan yang ketiga, urgensitas sebagai kajian ilmu. Informan berpendapat bahwa ada tiga alasan yang sangat urgen perlu dilakukan kajian Studi Syariat Islam di Aceh, yaitu:

"Pertama, Syariat Islam di Aceh secara filosofi itu adalah bahagian dari tata kehidupan masyarakat Aceh bahwa masyarakat Aceh dengan Islam tidak bisa dipisahkan. Karena memang dari sejarah sampai hari ini kalau orang bilang Islam itu Aceh dan Aceh itu Islam. Begitu kentalnya Islam di Aceh. 
Oleh karena itu, salah satu instrumen yang harus diketahui masyarakt terusmenerus adalah melalui mahasiswa. Syariat Islam itu bukan syariat Islam hari ini, akan tetapi dimulai dari sejarah awal masa Nabi dan sahabat, dinasti Bani Umayyah dan dinasti bani Abbas, kemudian dinasti-dinasti Islam kontemporer sampai kerajaan-kerajaan Islam hari ini. Jadi secara kultur itu penting. Kita bisa mendapatkan pengetahuan yang luas dari awal syariat Islam ada sampai bagaimana sejarah Islam masuk di Aceh, secara konteks negara bangsa”.

Alasan penting dilakukan kajian SI di Aceh di lembaga pendidikan tinggi disebabkan SI sangat mengakar dalam masyarakat Aceh. Nafas Islam sangat menyatu dalam adat budaya Aceh sehingga adat budaya kerap berazazkan Islam. ${ }^{21}$ Adat dan Islam merupakan kendali yang dominan dalam menggerakkan masyarakat Aceh, sukar untuk dipisahkan dan telah menjadi satu hukum yang telah melebur di dalamnya (hukum adat dan hukum Islam). Hadihmaja yang masih sangat kental dalam masyarakat Aceh hingga saat ini sangat disanjung "adat bak po teumeruhom, hukom bak Syah Kuala, Qanun bak Putroe Phang, Reusam bak Laksamana". ${ }^{22}$ Ajaran Islam yang menyatu dalam masyarakat Aceh yang telah membentuk identitas bangsa Aceh sejak masa awal penyebarannya di Aceh. ${ }^{23}$ Nilai-nilai hukum dan norma Islam telah menjadi pandangan hidup bagi masyarakat Aceh. ${ }^{24}$ Alasan kedua, disampaikan informan bahwa:

"Syariat Islam di Aceh itu sudah diformalkan oleh negara. Kalau sebelumnya syariat Islam tidak ada formalitas negara, tetapi sekarang syariat Islam di Aceh sudah mendapatkan formalitas dari negara. Artinya negara ikut bertanggung jawab dengan pelaksanaan syariat Islam di Aceh melalui regulasinya. Ada UU No. 11 2006, Tahun UU No. 44 tahun 1999, qanun-qanun. Ini harus diketahui oleh semua komponen masyarakat di Aceh bahwa syariat Islam di Aceh sudah menjadi urusan negara dan pemerintah, tidak lagi urusan pribadi. Oleh karena itu, aspek- aspek syariah, contohnya hukum publik tidak mungkin dilaksanakan tanpa ada kekuasaan negara. Sebagai contoh dalam konteks hukum pidana, negara yang bekerja disitu. dimensi ini tidak ada dalam provinsi lain di Indonesia. Apa buktinya? Pembentukan qanun itu negara

${ }^{21}$ Ali Geno Berutu. 2016. Penerapan Syariat Islam Aceh dalam Lintasan Sejarah.Jurnal Hukum, 13 (2) 2016: 163-188.

${ }^{22}$ Mohd. Din, Stimulasi Pembangunan Hukum Pidana Nasional dari Aceh untuk Indonesia, (Bandung: Unpad Press), hal.12.

${ }^{23}$ Yusny Saby, Apa Pentingnya Studi Aceh, dalam Jakfar Puteh, Sistem Sosial Budaya dan Adat Masyarakat Aceh (Yogyakarta: Grafindo Litera Media, 2012), hal. xxxi.

${ }^{24}$ Abidin Nurdin. Revitalisasi Kearifan Lokal di Aceh: Peran Budaya dalam Menyelesaikan Konflik Masyarakat Aceh. Analisis, XIII (1), 2013: 135-154. 
yang buat, gubernur dan DPRA. Yang menjalankan qanun katakanlah dalam konteks hukum pidana jinayah, yang menjalankannya kepolisian, kejaksaan, mahkamah syar'iyah dan mereka itu adalah institusi negara. Hal yang seperti ini harus diketahui oleh orang seluruh komponen".

Berdasarkan alasan tersebut maka terdapat perbedaan SI di Aceh, dimana sebelum lahirnya undang-undang penerapan SI, pelaksanaan SI adalah tanggung jawab individu namun kemudian setelah ada regulasi maka SI di Aceh berubah menjadi tanggung jawab negara. Untuk itu, SI di Aceh perlu dilakukan pengkajian secara akademik agar mahasiswa mengetahui, memahami, menerapkan serta mampu menganalisis bahkan menilai segala hal yang menyangkut penerapan SI di Aceh. Dengan demikian, mahasiswa sebagai agen yang akan kembali kepada masyarakat dapat membawa pengetahuan yang telah diperoleh sehingga terjadinya kesinambungan pengetahuan.

Secara historis terdapat perbedaan SI di Aceh dari masa ke masa. SI di Aceh telah ada dan digunakan sebagai norma hukum oleh masyarakat Aceh sejak masa kerajaan Islam Aceh pertama, yaitu Kerajaan Pasai hingga Kerajaan Islam Aceh Darussalam. ${ }^{25}$ Selanjutnya pada masa penjajahan dan pasca kemerdekaan Indonesia, SI di Aceh dapat dikatakan tahap perjuangan dan upaya untuk mendapatkan pengakuan dari pemerintah pusat (Indonesia). Pada akhirnya dengan berbagai gejolak yang terjadi dan perjuangan yang panjang, SI di Aceh diberi legalitas untuk dilaksanakan sebagai sub sistem dalam sistem hukum nasional. ${ }^{26}$ Dengan demikian SI di Aceh telah menjadi satu hukum yang diberlakukan di bumi Aceh dengan diberikan status hukum formal oleh pemerintah. Pengetahuan ini adalah awam di mata masyarakat sehingga perlu adanya pembelajaran secara formal pada lembaga-lembaga pendidikan.

Alasan ketiga, SI perlu dilakukan secara akademik dalam pandangan informan bahwa:

"banyak sekali persoalan syariat Islam ini tidak bisa kita wujudkan dalam tatanan negara kalau tidak dilakukan secara mendalam, kajian-kajian, tidak dilakukan penelitian-penelitian secara serius, tidak dilakukan penelitian tentang madzhab fiqih misalnya, teologi, tasawuf. Sehingga studi Syariat Islam di UIN sangat penting sebagai lahan untuk riset-riset tentang syariat Islam sehingga bisa menjadi sumbangan terhadap kebijakan Pemerintah Aceh".

Penerapan Syariat Islam di Aceh dalam dinamikanya tidak pernah lepas

\footnotetext{
${ }^{25}$ Hasanuddin Yusuf Adan, Islam dan Sistem Pemerintahan Aceh Masa Kerajaan Aceh Darussalam, (Banda Aceh: NASA, 2013), hal 35.

${ }^{26}$ Sulaiman, Studi Syariat Islam di Aceh, (Banda Aceh: Madani Publisher, 2018), hal. 40.
} 
dari gejolak, tantangan serta warna warni penegakannya. Isu-isu dalam penerapan Syariat Islam di Aceh tidak hanya menjadi isu lokal dan nasional bahkan telah menjadi isu hangat pada level internasional. Isu HAM, gender, hubungan muslim-non muslim menjadi isu yang hangat untuk dikaji dan diperdebatkan. Tidak hanya itu, isu-isu yang bersifat insidentil yang muncul dari kebijakan pemerintah, seperti isu "keharusan memakai rok bagi perempuan", isu "perempuan duduk di warung kopi", isu "perempuan duduk ngangkang di atas motor" dan lain sebagainya terjadi di bumi Aceh.

Oleh karena itu, kajian SI di Aceh perlu dilakukan secara akademik untuk menjawab berbagai persoalan-persoalan yang lahir dalam masyarakat, baik masyarakat Aceh, pandangan luar (nasional maupun internasional). Atas dasar itu pula, UIN Ar-Raniry sebagai lembaga yang kredibel di Aceh yang memiliki tanggung jawab terlaksananya SI di Aceh secara kaffah menambah satu kajian baru dalam kurikulumnya yaitu Studi Syariat Islam di Aceh. Harapannya penerapan SI di Aceh dapat membawa kemaslahatan bagi segenap masyarakat, terkhusus masyarakat Aceh. Maka sebagai bentuk dukungan perguruan tinggi adalah dengan kajian-kajian SI secara akademis melalui kurikuler, ko-kurikuler, ekstra kurikuler atau pusat-pusat studi syariat. Dalam hal ini informan berpandangan:

"keberadaaan mata kuliah Studi Syariat Islam di Aceh suatu kebutuhan, karena secara akademik yang mengetahui Syariat Islam di Aceh itu adalah UIN. Kita tidak boleh lepas tangan, bahkan sebetulnya yang harus lebih dikerjakan lagi. Kita harus memiliki pusat-pusat studi yang paling banyak tentang syariah ini, ada pusat studi tasawuf, pusat studi hukum, pusat studi teologi, pusat studi tafsir, yang bisa melakukan riset-riset tentang syariah. Jadi itu yang akan bermanfaat bagi pelaksanaan syariat Islam di Aceh".

Berdasarkan pandangan tersebut, lembaga UIN Ar-Raniry berperan dan bertanggung jawab terhadap keterlaksanaan SI di Aceh secara baik dan kaffah. UIN Ar-Raniry harus mampu menjadi rujukan, klinik dan pusat kajian SI. Siapa saja yang ingin mengetahui dan memahami tentang SI di Aceh, isu-isu yang berkembang maka UIN Ar-Raniry tempat rujukan dan kliniknya. UIN Ar-Raniry sebagai tempat untuk mendapatkan solusi, penyelesaian berbagai masalah dan persoalan yang tidak pernah sepi terjadi di bumi syariat, sehingga tidak terjadi kesalahpahaman dalam menyikapi pelaksanaan SI di Aceh. Selain itu, UIN Ar-Raniry sebagai konsultan bagi pemerintah dan pengambil kebijakan dalam menetapkan aturan-aturan terkait pelaksanaan SI di Aceh. Pada dasarnya perguruan tinggi dengan tri dharmanya dituntut untuk berpe- 
ran secara aktif positif dalam memecahkan permasalahan-permasalahan yang dihadapi masyarakat. ${ }^{27}$

\section{Kompetensi Mata Kuliah Studi Syariat Islam di Aceh}

Kompetensi merupakan sekumpulan yang dimiliki seseorang berkaitan dengan pengetahuan, keterampilan, sikap, dan nilai sebagai kinerja yang berpengaruh terhadap peran, perbuatan, prestasi, serta pekerjaan. Ellstrom dan Nilsson mendevinisikannya sebagai atribut/modal insani yang berupa kemampuan yang dihasilkan dari semua pengetahuan yang telah diakuisisi oleh seseorang (pengetahuan, afektif dan keterampilan sosial). KKNI menggunakan capaian pembelajaran (learning outcomes) yang memfokuskan pada apa yang diharapkan dapat dilakukan oleh peserta didik selama atau pada akhir suatu proses belajar.

Kompetensi atau capaian pembelajaran yang diharapkan melalui mata kuliah Studi Syariat Islam di Aceh adalah supaya mahasiswa mengetahui dan memahami SI serta aspek-aspeknya. Informan menjelaskan:

"Mahasiswa mengetahui dan memahami syariat Islam dan aspek-aspeknya mulai dari aqidah dan ibadah, yang paling penting adalah lahirnya produk qanun-qanun di Aceh. Kemudian lagi bagaimana syariat Islam sekarang, misalnya ada kasus di Bireuen peraturan minum kopi semeja maka penting dilakukan case study. Di Aceh Barat juga pernah ada kasus peraturan memakai rok bagi perempuan".

Capaian yang diinginkan tidak hanya terbatas pada pengetahuan tentang SI dan aspek-aspeknya. Akan tetapi pemahaman SI di Aceh sekarang ini adalah pemahaman hukum syariat dalam konteks bernegara. SI di Aceh mengatur tata kehidupan masyarakat yang berlandaskan Islam (Al-Quran dan Hadis) dalam bidang ibadah, muamalah, jinayah, akhlak dan lain sebagainya. ${ }^{28} \mathrm{Hal}$ ini perlu diketahui dan dipahami oleh mahasiswa. Pandangan informan bahwa:

"Kompetensi yang diharapkan pada mahasiswa, mereka mengetahui bahwa bicara Syariat Islam di Aceh bukan berbicara tentang konteks fiqih ibadah (seperti shalat, puasa) akan tetapi Syariat Islam dalam konteks bernegara. Dalam bahasa hukumnya, Syariat Islam di Aceh dijadikan panduan

${ }^{27}$ Sri Yuliawati, Kajian Implementasi Tri Dharma Perguruan Tinggi sebagai Fenomena Pendidikan Tinggi di Indonesia, http://media.neliti.com.publication, 2012, diakses pada 20 Oktober 2018.

${ }^{28}$ Misran, Pelaksanaan Syariat Islam di Aceh, Analisis Kajian Sosiologi Hukum, Legitimasi, Jurnal Hukum Pidana dan Politik Hukum, 1 (2) 2012: 1-15. 
berkehidupan masyarakat Aceh, bagaimana ibadahnya, muamalahnya, bagaimana berekonomi, bagaimana mendidik-mengajar, bagaimana sejarah Syariat Islam bercerita dari Tahun 1956, Tahun 1999, Tahun 2001 dan seterusnya. Wawasan keislaman inilah yang diharapkan".

Selain itu, melalui pengajaran mata kuliah Studi Syariat Islam di Aceh mahasiswa diharapkan tercapainya dua dimensi, yaitu transfer of knowledge (domain kognitif) dan transfer of value (kesadaran bersyariah atau domain afektif dan psikomotorik). Hal ini sebagaimana disampaikan informan:

"Kompetensi yang diharapkan melalui mata kuliah ini adalah tercapai dua dimensi, yaitu pertama, transfer of knowledge, yaitu pengetahuan tantang syariah yang dia dapatkan harus lengkap, komprehensif, multi perspekstif, mendalam mulai dari sejarah syariah dari masa awal sampai era kekinian. Oleh karena itu, dialog, pembelajaran kelas, diskusi dan beberapa yang lain menjadi instrumen untuk mendapatkan pengetahuan, termasuk di dalamnya riset-riset yang dilakukan untuk menambah pengetahuan mahasiswa tentang syariah dalam arti yang komprehensif." Kedua, kesadaran bersyariah, transfer of value, dengan mempelajari syariah akan merubah pola pikir, pola sikap dan pola tindak agar sesuai dengan syariah. Hal ini akan kita lihat dalam perilakunya sehari-hari. Kalau dalam ilmu tarbiyah kita melihat afektif dan psikomotorik. Harus dikembangkan pola menumbuhkan kesadaran syariah, bisa dalam konteks keteladanan, desain pola perilaku, atau aktifitas-aktifitas dalam masyarakat".

Transfer of knowledge adalah proses memindahkan pengetahuan dari satu bagian ke bagian lain. Transfer of knowledge mempunyai langkah-langkahnya, yaitu identifikasi (identifiying), menangkap (capturing), berbagi (sharing), menerapkan (appyling), evaluasi (assessing). ${ }^{29}$ Harapan dari pembelajaran mata kuliah Studi Syariat Islam di Aceh pada UIN Ar-Raniry adalah terjadinya proses transfer pengetahuan-pengetahuan tentang SI di Aceh kepada mahasiswa agar mereka mengetahui dan memahami SI di Aceh secara lengkap, mendalam, komprehensif, dan multi perspektif. Selanjutnya melalui pengetahuan dan pemahaman akan terpatri dalam wujud sikap individu (to be), sikap sosial (to live together) dan wujud praktik (to do) dalam kehidupan sehari-hari, baik secara individu dan aktifitas-aktifitas dalam masyarakat sebagai bentuk dari transfer of value.

${ }^{29}$ Vincentius Widya Iswara, Chatarina Eka OcKtavila dan Murad Maulana. Implementasi Knowledge Transfer Repositori Perguruan Tinggi pada Indonesia One Search. http//:core. ac.uk.download.pdf. Diakses pada 10 Oktober 2018. 


\section{PENUTUP}

Lahirnya mata kuliah Studi Syariat Islam di Aceh dalam kurikulum UIN Ar-Raniry dilatar belakangi oleh beberapa faktor yaitu; (1) perubahan nomenklatur lembaga. IAIN Ar-Raniry resmi menjadi UIN Ar-Raniry sejak dikeluarkannya Peraturan Presiden Nomor 64 Tahun 2013 dan Peraturan Menteri Agama (PMA) Republik Indonesia No 12 Tahun 2014 yang perubahan ini berdampak pada sistem lembaga yang salah satu unsurnya adalah kurikulum. Salah satu perubahan kurikulum adalah dengan internalisasi mata kuliah Studi Syariat Islam di Aceh. (2) Mata kuliah Studi Syariat Islam di Aceh dipandang sebagai karakteristik atau kekhasan yang dimiliki daerah Aceh yang perlu diajarkan dalam lembaga pendidikan tinggi, dan (3) Syariat Islam di Aceh dinilai sangat urgen untuk dikaji secara akademik disebabkan banyak persoalan syariat perlu kepada pengkajian-pengkajian dan yang mampu melakukannya adalah perguruan tinggi Islam.

Kompetensi yang diharapkan dicapai oleh mahasiswa dalam perkuliahan mata kuliah Studi Syariat Islam di Aceh adalah kemampuan memahami SI dan penerapannya di Aceh secara mendalam dan komprehensif sebagai panduan berkehidupan. Melalui pembelajaran diharapkan tercapai transfer of knowledge (domain kognitif) sebagai kemampuan dalam mengetahui, memahami, menerapkan, menilai dan mengevaluasi tentang pelaksanaan SI di Aceh. selain itu juga diharapkan terwujudnya kesadaran bersyariah (domain afektif dan psikomotorik) dalam kehidupan sehari-hari, baik secara individu maupun dalam berkehidupan sosial mayarakat. 


\section{DAFTAR PUSTAKA}

Abdullah Sani Usman. Cabaran dan Halangan dalam Pelaksanaan UndangUndang Jenayah Syariah Islam. Jurnal Pengajian Umum Asia Tenggara. Vol. 12, 2011 : 5-14.

Abidin Nurdin. Revitalisasi Kearifan Lokal di Aceh: Peran Budaya dalam Menyelesaikan Konflik Masyarakat Aceh. Analisis, XIII (1), 2013: 135-154.

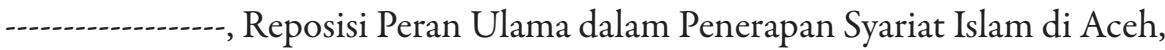
Jurnal Al-Qalam, 18 (1) 2012: hal. 60.

Ahmad, dkk., Islam dalam Pendidikan dan Hubungannya dengan Pembentukan Jati Diri Bangsa Melayu di Malaysia. Jurnal Hadhari Special Edition, 2012: 37-50.

Ali Geno Berutu. Penerapan Syariat Islam Aceh dalam Lintasan Sejarah. Jurnal Hukum, 13 (2) 2016: 163-188.

Azman Ismail, dkk. Syariat Islam di Nanggroe Aceh Darussalam. Banda Aceh: Dinas Syariat Islam, 2011.

Hasanuddin Yusuf Adan. Islam dan Sistem Pemerintahan Aceh Masa Kerajaan Aceh Darussalam. Banda Aceh: NASA, 2013.

-, Syariat Islam dan Politik Lokal di Aceh. Banda Aceh: 'Adnin Foundation Group, 2016.

Refleksi Implementasi Syariat Islam di Aceh. Banda Aceh: Adnin Foundation Publisher, 2009.

Marwan Salahuddin, Model Pengembangan Pendidikan Tinggi Islam di Indonesia, Jurnal Studi Keislaman Ulumuna, 18 (1) 2014: 121-138.

Misran, Pelaksanaan Syariat Islam di Aceh, Analisis Kajian Sosiologi Hukum, Legitimasi, Jurnal Hukum Pidana dan Politik Hukum, 1 (2) 2012: 1-15.

Mohd. Din. Stimulasi Pembangunan Hukum Pidana Nasional dari Aceh untuk Indonesia. Bandung: Unpad Press, 2009.

Muhammad Hendra. Pendidikan Agama Islam. Yogyakarta: Deepublish, 2014.

Muhibbuthabry, Kelembagaan Wilayat Al-Hisbah di Aceh (Konsep dan Implementasi. Banda Aceh: Pena, 2010. 
Mujiburrahman, dkk. Pendidikan Berbasis Syariat Islam di Aceh. Banda Aceh: Dinas Syariat Islam Aceh, 2011.

M. Syaltout. Islam: Aqidah wa Syariah. Cairo: Dar al-Qalam, 1966.

Nana Sudjana. Dasar-dasar Proses Belajar Mengajar. Bandung: Sinar Baru Algesindo, 2005.

Sirajuddin M, Legitimasi Pemberlakukan Syariat Islam di NAD: Analisis Prinsip-prinsip dan Peluang Yuridis Konstitusional, SOSIO RELIGIA, 10(1): 74 .

Sri Yuliawati, Kajian Implementasi Tri Dharma Perguruan Tinggi sebagai Fenomena Pendidikan Tinggi di Indonesia, http://media.neliti.com. publication, 2012, diakses pada 20 Oktober 2018.

Sulaiman. Studi Syariat Islam di Aceh. Bnada Aceh: Madani Publisher, 2018.

Syamsul Bahri, Konsep Implementasi Syariat Islam di Aceh. Kanun Jurnal Ilmu Hukum, 60 (XV), 2012: 313-337.

Vincentius Widya Iswara, Chatarina Eka OcKtavila dan Murad Maulana. Implementasi Knowledge Transfer Repositori Perguruan Tinggi pada Indonesia One Search. http//:core.ac.uk.download.pdf. Diakses pada 10 Oktober 2018.

Yusny Saby, Apa Pentingnya Studi Aceh, dalam Jakfar Puteh, Sistem Sosial Budaya dan Adat Masyarakat Aceh. Yogyakarta: Grafindo Litera Media, 2012. 